\title{
On the use of a beam infiltration water intake structure for water supply purposes
}

\author{
Ruslan Shamsutdinov ${ }^{1}$, Irina Trotsenko ${ }^{1 *}$, Yulia Korchevskaya $^{1}$, and Eduard Nazarkin ${ }^{4}$ \\ ${ }^{1}$ Omsk State Agrarian University named after P.A. Stolypin, 1, str. Institskaya Square, 644008, Omsk, \\ Russia \\ ${ }^{2}$ Russian State Agrarian University - Moscow Agricultural Academy named after K.A. Timiryazev, \\ 49, str. Timiryazevskaya, 127550, Moscow, Russia
}

\begin{abstract}
The object of research in this work is the under-channel waters of the Irtysh River, considered as an alternative source of water supply, necessary for the sustainable provision of high-quality drinking water to the population of cities in emergency situations. In bacteriological and sanitary-hygienic terms, studies have shown that infiltration waters are quite safe. According to the results of the analyzes carried out, infiltration waters are mainly fresh with a salinity of 0.5 to $1 \mathrm{~g} / 1$. The most rational scheme from a technical and economic point of view in relation to local conditions are beam water intake structures, which is due to the relatively low thickness of water-bearing rocks. At the same time, infiltration-type water intake structures in the Irtysh river valley should be located at a distance of up to $130 \mathrm{~m}$ from the river channel (taking into account the value of hydraulic resistance $\Delta \mathrm{l} H$ ). The distance between wells in a linear row should be taken up to $50 \mathrm{~m}$.
\end{abstract}

\section{Introduction}

Water pollution is a serious environmental problem. Its pollution makes it impossible to use surface water for drinking purposes, and existing water purification methods are not always able to solve this problem. There is already a shortage of fresh water in the world (mainly in regions close to the equator). The pollution of water bodies only aggravates the state of affairs. All this threatens the lack of fresh water for a large number of people [1, 2, $3]$.

In connection with the current situation, it becomes necessary to search for alternative sources of water supply and design water intake facilities for household and drinking purposes.

The object of research in this work is the under-channel waters of the Irtysh River in the city of Omsk, for which, as for many cities, the problem of the lack of an alternative source of water supply, which is so necessary for the sustainable provision of high-quality drinking water to the population in emergency situations, is acute.

In the city of Omsk in the 1970 s, research was carried out by scientists from the Omsk Agrarian University in search of an alternative source of water supply. The ground and

${ }^{*}$ Corresponding author: ia.trotsenko@omgau.org 
infiltration underflow waters of the Irtysh River were considered. Within the islands located in the bed of the Irtysh River, 24 wells were drilled and tested. As a result of research, scientists (Goyan V.V., Kuzmin A.I. and others) concluded that groundwater has high mineralization, in contrast to infiltration. Therefore, the infiltration under-channel waters of the Irtysh River were considered as an alternative source [4,5].

In bacteriological and sanitary-hygienic terms, studies have shown that infiltration waters are quite safe.

According to the results of the analyzes carried out, infiltration waters are mainly fresh with a salinity of 0.5 to $1 \mathrm{~g} / \mathrm{l}$. Also, a comparison was made with indicators of the quality of drinking water (table 1) [6].

Table 1. Analysis data of infiltration waters of Zakhlaminsky Island (Irtysh River).

\begin{tabular}{|l|c|c|c|}
\hline \multicolumn{1}{|c|}{ Indicators } & $\begin{array}{c}\text { Irtysh river water } \\
\text { (during 1968) }\end{array}$ & Infiltration water & $\begin{array}{c}\text { SanPin 2.1.4.1116- } \\
\text { 02 Drinking water }\end{array}$ \\
\hline Transparency. cm & 43.8 & 4.5 & $>30$ \\
\hline Oxidability. mg/l & 8.2 & 0.3 & $<3$ \\
\hline $\begin{array}{l}\text { Ammonia nitrogen. } \\
\mathrm{mg} / \mathrm{l}\end{array}$ & 0.41 & неt & $<0.1$ \\
\hline Nitrite. mg/l & 0.9 & неt & $<3.0$ \\
\hline Nitrates. mg/1 & 1.6 & неt & $<45$ \\
\hline BOD & 2.4 & неt & $<3$ \\
\hline Coli-titer & 0.4 & более 333 & $>300$ \\
\hline $\begin{array}{l}\text { The total number of } \\
\text { bacteria in 1 ml }\end{array}$ & 25600 & 50 & $<50$ \\
\hline Volatile phenols & 0.01 & неt & $<0.001$ \\
\hline
\end{tabular}

Table 1 shows that the quality of infiltration water corresponds to the quality of drinking water. When drawing up a technological scheme of water supply, it is necessary to take into account these indicators, which make it possible to simplify the technology of water treatment.

\section{Methods}

The first structure in the water supply scheme is a water intake structure. For the intake of infiltration water, the following types can be used: vertical, horizontal, beam and combined $[7,8,9,10]$.

The complex of studies carried out in the exploration areas and the analysis of the obtained factual material made it possible to select, in relation to local conditions, the most acceptable schemes of infiltration-type water intake structures. The analysis of hydrogeological conditions and the results of regime observations, together with the calculations of operational reserves, made it possible to select the following schemes of infiltration structures on the studied islands in the river Irtysh valley:

1) a linear row of vertical wells located on an island along the river bank with a siphon collecting water conduit;

2) a linear row of vertical wells equipped with EPL-6 artesian pumps;

3) beam intake structures;

4) water intakes with a ring drain (a type of radial water intake).

During the research, a feasibility study was carried out (table 2) 
Table 2.Technical and economic indicators of various schemes of water intake facilities (capacity $10,000 \mathrm{~m}^{3} /$ day).

\begin{tabular}{|l|c|c|c|c|}
\hline $\begin{array}{c}\text { Types of water } \\
\text { intakes }\end{array}$ & $\begin{array}{c}\text { Construction } \\
\text { cost. thousand } \\
\text { rubles }\end{array}$ & $\begin{array}{c}\text { Annual operating } \\
\text { costs. thousand } \\
\text { rubles }\end{array}$ & $\begin{array}{c}\text { Present } \\
\text { value. } \\
\text { thousand } \\
\text { rubles }\end{array}$ & $\begin{array}{c}\text { Prime cost of 1 } \\
\mathbf{m}^{\mathbf{3}} \text { of water } \\
\text { (free-reservoir } \\
\text { of clean } \\
\text { water). rubles }\end{array}$ \\
\hline Coastal river & 50990 & 25806.8 & 30905.8 & 8.46 \\
\hline $\begin{array}{l}\text { Infiltration linear } \\
\text { with siphon } \\
\text { water conduit }\end{array}$ & 24056 & 14284.2 & 16689.8 & 4.58 \\
\hline $\begin{array}{l}\text { Infiltration linear } \\
\text { with artesian } \\
\text { pumps EPL-6 }\end{array}$ & 26198 & 17405.6 & 20025.4 & 5.44 \\
\hline Infiltration beam & 17063.2 & 13158.4 & 14684.8 & 4.08 \\
\hline $\begin{array}{l}\text { Infiltration beam } \\
\text { with ring drain }\end{array}$ & 16624 & 13175.4 & 14837.8 & 4.06 \\
\hline
\end{tabular}

As a result of the feasibility study, it was revealed that the lowest present value is typical for infiltration ray water intakes. In addition, this scheme is the most rational scheme, since the radial water intake allows you to concentrate the pumping means compactly in one place and gives the following advantages: significantly reduces the length of the collection conduits; allows you to bring the water intake closer to the consumer; during operation, maintenance personnel are in one place, facilitates equipment control, installation of automation and instrumentation; significantly reduces the size of the alienated territory when installing sanitary protection zones and reduces energy consumption.

Therefore, the article proposed this type of water intake structure.

For the beam water intakes, the mine is designed with a reinforced concrete diameter of $5 \mathrm{~m}$. Its construction is carried out by the lowering method with hydraulic excavation of the soil: six beam mesh filters are installed using casing pipes [10].

On small islands $r$. It is advisable to lay the under-channel water intakes on the Irtysh, since during their operation the river will quickly limit the development of the depression funnel. On large islands it is more expedient to lay coastal infiltration intakes located along one or both coasts of the island.

The calculations of the radial water intakes were performed according to the equation of G.A. Razumov. Distances of all water intake structures from the river, taking into account the value $\Delta \mathrm{l}_{\mathrm{n}}$ received $130 \mathrm{~m}$.

For illustration, we present the calculation of a linear series of onshore infiltration water intake wells within 1 block.

Initial data:

$\mathrm{m}=10,0 \mathrm{~m}-$ aquifer thickness;

$\mathrm{K}=32,9 \mathrm{~m} /$ day - filtration coefficient;

$\mathrm{S}_{\mathrm{add}}=5,0 \mathrm{~m}$ - permissible lowering of the water level in the center of the linear row;

$\mathrm{Q}=10000 \mathrm{~m}^{3} /$ day - prospective water consumption of a nearby settlement;

$\mathrm{r}_{0}=0,15 \mathrm{~m}$ - radius of the working part of the filter;

$\lambda$ - distance between wells in a linear row.

To obtain optimal values, we preset the number of wells (n) and the distance between them $(\lambda)$. Then, using the calculation formulas, we determine the decrease in the level in the center of the water intake and compare it with the permissible one.If the allowable decrease is less than the calculated one, then we make repeated calculations with the appointment of other calculated parameters ni $\lambda$. 
Calculations of radial water intakes were made according to the formula of G.A. Razumov:

$$
Q_{n}=\alpha \frac{2 \pi k s l}{F(u \pi)} \delta n
$$

where $\mathrm{k}$ - filtration coefficient, $\mathrm{m} /$ day;

$\mathrm{s}-$ projected lowering of the level in the well, $\mathrm{m}$;

1 - beam length, $\mathrm{m}$;

$\alpha$-parameter providing for a decrease in the flow rate of the beam, depending on its decrease along the height of the aquifer relative to its middle, that is, depending on $\frac{z_{0}}{m}$, and is determined according to the schedule;

$\delta$ - coefficient taking into account the decrease in the flow rate of the water intake due to the influence of its rays, is determined according to the schedule;

$\mathrm{n}$-number of rays;

$$
F\left(\mathrm{u}_{\pi}\right)=\mathrm{I}_{\mathrm{n}}\left(\frac{0,74 l}{r_{0}} \sqrt{\frac{2 R-l}{2 R+l}}\right)+2 \cdot \mu \cdot \operatorname{In} \cdot u_{\pi}
$$

In the expression

$$
u_{\pi}=\frac{l+\sqrt{l^{2}+4 m^{2}}}{2 m} \cdot \sqrt{\frac{2 R-l}{2 R+l}},
$$

where $\mathrm{R}$ - double distance from the mine to the water's edge, $\mathrm{m}$;

$\mu$ - coefficient,determined according to the schedule[9].

\section{Results}

To calculate the flow rate of the radial water intake, the following parameters and selected structural elements of the water intake are taken: the diameter of the shaft well is $5 \mathrm{~m}$; wall thickness $0.6 \mathrm{~m}$; the depth of the mine well buried in the ground - $12 \mathrm{~m}$; shaft fastening reinforced concrete.

The shaft well provides for 6 horizontal drainage beams $30 \mathrm{~m}$ long, located at an angle of $60^{\circ}$ to each other.

Thus, for 1 block, the calculated parameters are as follows:

$\mathrm{n}=6 \mathrm{~m} ; 1=30 \mathrm{~m} ; \mathrm{r}_{0}=0,1 \mathrm{~m} ; \mathrm{m}=10 \mathrm{~m} ; \mathrm{S}_{\text {add }}=6,0 \mathrm{~m} ; \mathrm{k}=32,0 \mathrm{~m} /$ day; $\mathrm{R}=130 \mathrm{~m}$.

Substituting these quantities into formulas (1), (2), and (3), we obtain:

$$
\begin{gathered}
u_{\pi}=\frac{30+\sqrt{900+400}}{20} \cdot \sqrt{\frac{260-30}{260+30}}=2,97 \\
F\left(u_{\pi}\right)=I_{n}\left(\frac{0,74 \cdot 30}{0,1} \cdot \sqrt{\frac{260-30}{260+30}}\right)+2 \cdot \mu \cdot I_{n} \cdot 2,97
\end{gathered}
$$

$\mu=2,7$. Determined by G.A. Razumov [8].

then

$$
\mathrm{F}\left(\mathrm{u}_{\pi}\right)=\ln 177,6+2 \cdot 2,7 \ln 2,97=5,2+5,9=11,1
$$

By equation (1) we find:

$$
Q=\alpha \cdot \frac{6,28 \cdot 32,9 \cdot 5 \cdot 30 \cdot 6}{11,1}
$$


$\alpha=1 ; \delta=0,55$. Determined by G.A. Razumov [9].

then

$$
Q=1 \cdot \frac{6,28 \cdot 32,9 \cdot 5 \cdot 30 \cdot 0,55 \cdot 6}{11,1} \approx 10000 \mathrm{~m}^{3} / \text { day }
$$

In further calculations of the beam intakes, we take the value of 1 equal to $30 \mathrm{~m}$.

Thus, the most rational scheme from a technical and economic point of view in relation to local conditions are beam water intake structures, which is due to the relatively low thickness of water-bearing rocks. At the same time, infiltration-type water intake structures in the Irtysh river valley should be located at a distance of up to $130 \mathrm{~m}$ from the river channel (taking into account the value of hydraulic resistance $\Delta \ln$ ). The distance between wells in a linear row should be taken up to $50 \mathrm{~m}$.

Since, according to Table 1, the quality indicators of infiltration waters are within the normative limits, respectively, the water supply system will consist of a water intake well, a submersible pump, which will be located in the well, take and supply water to the clean water reservoir with further disinfection and supply of water to consumers. 1.

The infiltration water intake structure of the beam type is designed and shown in Figure

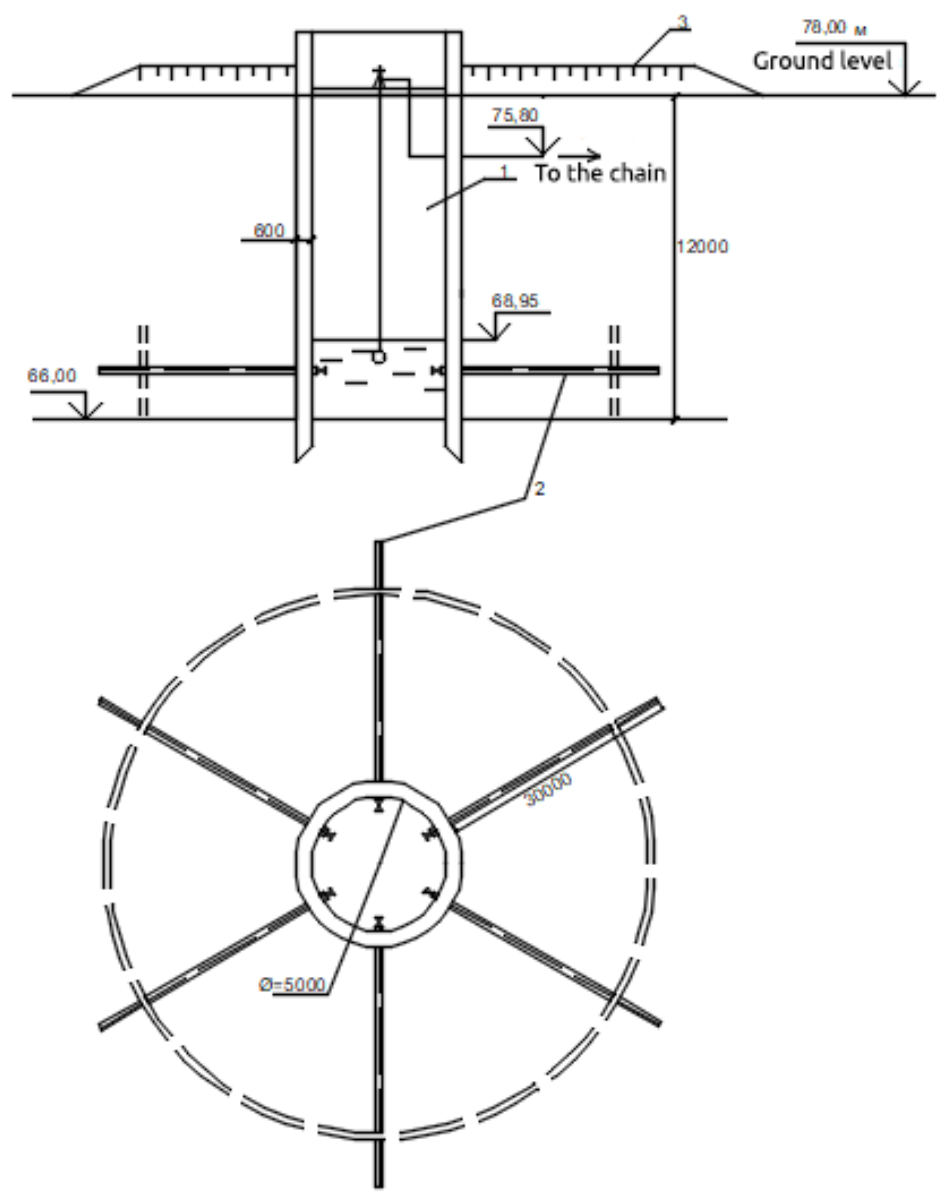

Fig. 1. Beam infiltration water intake structure. Where: 1 - water intake well, 2 - beam filters, 3 earth dams 
The equipment of beam water intakes consists of a water-lifting unit, connecting, suction and pressure water lines, valves and control and measuring equipment $[11,12,13$, 14].

The pump is selected according to flow rate and head. For the selection of pumping equipment, the following calculation method is proposed.

Consumption is determined by the formula:

$$
q_{p}=\frac{q_{\text {calc } \mathrm{B} 3}}{n}, \mathrm{~m}^{3} / \mathrm{s}
$$

where $\mathrm{q}_{\mathrm{calc}} B 3$ - calculatedn water intake. Corresponds to the water intake capacity $\mathrm{Q}=10000 \mathrm{~m}^{3} /$ day $\rightarrow 0,116 \mathrm{~m}^{3} / \mathrm{s}$

$\mathrm{n}$ - number of working pumps, pcs.

According to the estimated flow rate, category I of the degree of water supply was selected, and accordingly, 2 working and 1 standby pump were selected [15]. then

$$
q_{p}=\frac{0,116}{2} m^{3} / \mathrm{s}=0,058 \mathrm{~m}^{3} / \mathrm{s}
$$

The required pump head is determined in the usual way. It is composed of the geometrical height of the water rise, hydraulic losses in the riser pipe of the pumping station and the pressure collecting pipeline [15]:

$$
\mathrm{Hr}=\mathrm{Hgr}+\mathrm{h} p d+\text { hout, } m
$$

where $\mathrm{H}_{\mathrm{gu}}$ - geometric height of water rise, $\mathrm{m}$;

$\mathrm{h}_{\mathrm{pd}}$ - head loss in the discharge pipeline, $\mathrm{m}$;

$\mathrm{h}_{\text {out }}$ - outflow loss, $\mathrm{m}$ Accepted from 1.5 to $2 \mathrm{~m}$.

Since it is planned that water will be supplied from the well to the water consumer's network, the geometric height of the rise will be determined from the dynamic water level in the well to the mark at the junction in this place.

Accordingly, the geometric height of water rise:

$$
H g r=\nabla-\operatorname{Lin}, m
$$

where $\nabla$ - supply mark to water consumers, $\mathrm{m}$. Accepted $=75.80 \mathrm{~m}$

$\mathrm{L}_{\min }-$ minimum water level in the receiving tank (dynamic water level in the well), $\mathrm{m}$.

Determined by the formula:

$$
\operatorname{Lmin}=\operatorname{Linf}-h 0, m
$$

$\operatorname{Linf}=69,0 \mathrm{~m}-$ mark of infiltration water levels in Zakhlaminsky island $\mathrm{h}_{0}$ - pressure loss in the radial water intake, $\mathrm{m}$ Determined by the formula:

$$
h_{0}=\left(2+\frac{\lambda \cdot L}{6 \cdot r_{0}}\right) \cdot \frac{V^{2}}{2 g}, m
$$

where $\lambda$-hydraulic coefficient of friction. For pipes with a diameter of $50 \ldots 300 \mathrm{~mm} \lambda=$ $(0.08 \ldots 0.1)$. Since the pipe diameter is $d=300 \mathrm{~mm}$, then $\lambda=0,1$

$\mathrm{Q}$ - water consumption, $\mathrm{m}^{3} / \mathrm{s}$. $\mathrm{Q}=10000 \mathrm{~m}^{3} /$ day $\rightarrow 0,116 \mathrm{~m}^{3} / \mathrm{sec}$

$\mathrm{V}-$ speed of water flow in rays, $\mathrm{m} / \mathrm{s}$. Determined by the formula:

$$
V=\frac{Q}{2 \pi r_{0}^{2} \cdot N}, \mathrm{~m} / \mathrm{s}
$$

Substitute the values into formulas (8) and (9): 


$$
\begin{gathered}
V=\frac{0,116 \mathrm{~m}^{3} / \mathrm{s}}{2 \cdot 3,14 \cdot 0,1 \cdot 6}=0,377 \mathrm{~m} / \mathrm{s} \\
h_{0}=\left(2+\frac{0,1 \cdot 30}{6 \cdot 0,15}\right) \cdot \frac{0,377^{2}}{2 \cdot 9,81}=0,05 \mathrm{~m}
\end{gathered}
$$

then:

$$
\begin{aligned}
\operatorname{Lmin} & =69,0 m-0,05 m=68,95 m \\
H_{g u} & =75,80 m-68,95 m=6,85 m
\end{aligned}
$$

To determine the head loss in the pressure pipeline, you must first set the diameter of the pressure pipeline:

$$
d p d=\sqrt{\frac{4 \times q_{p}}{\pi \times V_{p r}}}, m
$$

$\mathrm{q}_{\mathrm{p}}$ - pump capacity equal to $0,058 \mathrm{~m}^{3} / \mathrm{sec}$

$\mathrm{V}_{\mathrm{pr}}$ - the velocity in the pressure pipeline is taken from 2.0 to $3.0 \mathrm{~m} / \mathrm{s}$. Then:

$$
d p d=\sqrt{\frac{4 \times 0,058}{3,14 \times 2,5}}=0,17 \mathrm{~m} .
$$

Standard diameter of $200 \mathrm{~mm}$ was adopted and the speed of water movement in it was refined using the formula:

$$
\begin{gathered}
V p r=\frac{4 \times q_{p}}{\pi \times d_{c h t p}^{2}}, \mathrm{~m} / \mathrm{s} \\
V p r=\frac{4 \times 0,058}{3,14 \times 0,2^{2}}=1,85 \mathrm{~m} / \mathrm{s}
\end{gathered}
$$

The total head losses are determined by the formula:

$$
h_{\text {gen }}=1,2 \cdot L \frac{1000 i}{1000}, m
$$

where $L$ - pressure line length, $1000 \mathrm{~m}$.

By consumption $\mathrm{q}_{\mathrm{p}}=0,058 \mathrm{~m}^{3} / \mathrm{secand}$ diameter $\mathrm{d}_{\mathrm{n}}=200 \mathrm{~mm}$, pipeline material steel according to Shevelev's table the following parameters are adopted: $\mathrm{V}=1000 \mathrm{i}=23,4, \mathrm{~V}=$ $1,69 \mathrm{~m} / \mathrm{sec}$.

Then:

$$
\begin{gathered}
h_{\text {gen }}=1,2 \cdot 1000 \frac{23,4}{1000}=28,08 m \\
H p=6,85 m+28,08 m+2 m=36,93 m
\end{gathered}
$$

Due to the parameters: $\mathrm{H}_{\mathrm{p}}=36,93 \mathrm{mandQ}_{\mathrm{p}}=208,8 \mathrm{~m}^{3} / \mathrm{hthe}$ pump ETsV 12-250-35 was selected.

\section{Conclusion}

Before using water from surface water sources for domestic and drinking water supply, it is necessary to apply various treatment methods, which involve various expensive structures. 
In this regard, now there is a need to search for alternative sources of water supply in many large cities. One such alternative source is infiltration water, which has many advantages over other groundwater. Intensive feeding from the river channels allows infiltration water intakes, all other things being equal, to take much higher water flow rates than water intakes of conventional groundwater supply. Moreover, when the river waters move to the intake facilities, these waters are purified, therefore, most of the operated water intakes supply water devoid of suspended solids and containing no harmful impurities. From a sanitary and hygienic point of view, infiltration waters are overwhelmingly irreproachable. In addition, infiltration waters compare favorably with river waters by the relative constancy of water temperature throughout the year. The relatively shallow depth of wells in alluvial deposits in sufficiently high water inflows allows solving the problem of water supply.

On the example of the Irtysh River, the most rational type of water intake structure was calculated and selected using infiltration waters - a beam intake with 4-6 horizontal beams. Considering the complex and varied conditions of localization of alluvial deposits. When determining the location of the water intake structures, it is necessary to conduct hydrogeological studies.

The use of alternative water sources can solve the problem of water supply in large cities.

\section{References}

1. Report on the environmental situation in the Omsk region for 2018. Ministry of Natural Resources and Ecology of the Omsk Region (LLC «Omskblankizdat», Omsk, 2019)

2. On the state of sanitary and epidemiological well-being of the population in the Russian Federation in the Omsk region in 2017: Materials for the state report. - Office of the Federal Service for Supervision of Consumer Rights Protection and Human Welfare in the Omsk Region (2018)

3. Zh.A. Tusupbekov, N.L. Ryapolova,V.S. Nadtochiy, IOP Conf. Series: Earth and Environmental Science 624, 012235 (2021) doi:10.1088/1755-1315/624/1/012235

4. A.I. Kuzmin, R.G. Shamsutdinov, Materials of the All-Russian (national) conference dedicated to the 90th anniversary of the irrigation and drainage faculty of the Omsk Agricultural Institute. "Actual problems of environmental management, water use, agrochemistry, soil science and ecology" (Omsk, 2019)

5. O.Yu. Pobereznichenko, T.P. Khomutetskaya, Engineering and construction journal. 2(46), 58-64 (2014) DOI: 10.5862/MCE.46.7

6. A.I. Kuzmin, R.G. Shamsutdinov, P.S. Tkachev, Materials of the All-Russian (national) conference dedicated to the 90th anniversary of the irrigation and drainage faculty of the Omsk Agricultural Institute "Actual problems of environmental management, water use, agrochemistry, soil science and ecology" (Omsk, 2019)

7. A.S. Babkin, I. Zh. Atabiev, V.P. Bukreev, B.M. Bakhtin, Environmental management 5, 36-41 (2018) DOI: 10.26897/1997-6011/2018-5-36-41

8. M.S. Rysin, I.A. Lushkin, Proceedings of the IV All-Russian scientific and practical conference (correspondence) "Urban planning, reconstruction and engineering support for the sustainable development of cities in the Volga region", 179-185 (2015)

9. A.I. Matyushenko, Journal of the Siberian Federal University. Series: Technique and technology 8(2), 232-237 (2015)

10. Yu.A. Feofanov, M.S. Ryakhovsky, Water Magazine 8(132), 38-41 (2018) 
11. N.I. Kovalev, L.I. Lukina, V.S. Pashtetsky et al., Collection of articles based on the materials of the international scientific and practical conference "Environmental, industrial and energy security - 2019", 780-788 (2019)

12. Yu.V. Korchevskaya, I.G. Ushakova, I.A. Trotsenkoand, G.A. Gorelkina, IOP Conference Series: Earth and Environmental Science 579(1) (2020)

13. I. Ushakova, Y. Korchevskaya, I. Trotsenko, T. Kondrateva, Education and Humanities Research 393, 36-41 (2019)

14. Seiichiro Takai, Wide area water collection type underground water tank: pat. 6,382,237 B1 / PCT/JP99/05829 №09/830,549 (2000)

15. C.M. Chini, R.A. Peer, Scientific Data 8(1) (2021) 